\title{
THINK PAIR SHARE UNTUK MENINGKATKAN AKTIVITAS DAN HASIL BELAJAR MATEMATIKA SISWA KELAS IV SDN 1 PURWOSARI TAHUN PELAJARAN 2013/2014
}

\author{
Alis Suryanti \\ Guru SDN 1 Purwosari Kec. Padangratu \\ E-mail: Alissurnyanti@gmail.com
}

\begin{abstract}
The aims of this research were to increase the activity and study result of student by implementation of Cooperative Learning Tipe Think Pair Share. The method of the research was Classroom Action Reserach. The instrument of data collection used observation sheet, formatif test sheet, and documentation. Technique of data analysis used qualitative and quantitative analysis. The result showed that the student activity in cycle I 52,91\% (Moderately Active), in cycle II 63,24\% (Active) to be $77,49 \%$ (Active) in cycle III. Percentage of the study completeness in cycle I $57,44 \%$, in cycle II 70,22\% to be $85,11 \%$ in cycle III.
\end{abstract}

Keywords: activity, study result, think pair share

\section{PENDAHULUAN}

Pendidikan adalah usaha sadar yang dilakukan melalui kegiatan atau latihan untuk mengubah sikap serta untuk mendewasakan diri supaya mampu menyesuaikan diri dengan lingkungan. Dalam proses pembelajaran diperlukan peran dan tanggung jawab guru dalam mendidik, mengajar, serta menjadi fasilitator bagi siswanya dalam setiap bidang pengajaran, salah satunya adalah matematika. Pembelajaran matematika khususnya untuk sekolah dasar pada prosesnya berpedoman pada tiga konsep kurikulum SD, yaitu penanaman konsep dasar, pemahaman konsep, dan pembinaan keterampilan, Heruman (2008: 2).
Berdasarkan hasil nilai semester ganjil siswa kelas IV SDN 1 Purwosari diketahui bahwa hasil belajar siswa masih banyak dibawah kriteria ketuntasan minimal (KKM) yaitu 60. Dari 24 jumlah siswa yang terdiri dari 10 orang siswa laki-laki dan 14 orang siswa perempuan, sebanyak 13 siswa atau 54\% belum mencapai KKM dan hanya 11 siswa atau $46 \%$ mencapai KKM. Kendala yang menjadi penyebab rendahnya hasil belajar siswa adalah kondisi siswa yang kurang aktif atau randahnya aktivitas siswa ketika pembelajaran berlangsung seperti banyaknya siswa yang mengobrol, melamun/mengantuk, dan mengganggu temannya serta 
kurang perhatian siswa ketika guru menyampaikan materi pembelajaran. Hal ini berdasarkan hasil observasi yang dilakukan peneliti terhadap proses pembelajaran matematika di kelas IV. Selain itu, pembelajaran masih bersifat one way traffic communication (pembelajran dengan komunikasi satu arah) yang berpusat pada guru cenderung membuat siswa pasif sehingga membosankan siswa. Oleh karena itu guru perlu menciptakan kondisi kelas yang menyenangkan. Salah satu model pembelajaran yang dinilai dapat menciptakan suasana kelas yang menyenangkan adalah model cooperative learning. Dari berbagai macam model-model cooperative learning, model cooperative learning tipe think pair share dianggap sebagai model pembelajaran yang dapat membuat siswa aktif dalam pembelajaran, mencapai hasil pembelajaran yang lebih baik, dan mampu mengembangkan kemampuan berpikir kritis siswa.

Berdasarkan beberapa permasalahan di atas, perlu adanya upaya perbaikam pada pembelajaran matematika melalui penelitian tindakan kelas, sehingga dalam penelitian ini peneliti mengangkat judul "Penerapan Model Cooperative Learning Tipe Think Pair Share Untuk Meningkatkan Aktivitas dan Hasil
Belajar Pada Pembelajaran Matematika Kelas IV SDN 1 Purwosari Tahun Pelajaran 2013/2014".

Menurut Arends (dalam Komalasari, 2011: 64) menyatakan bahwa think pair share merupakan suatu cara yang efektif untuk membuat variasi suasana pola diskusi siswa. Sedangkan menurut Lie (2005: 57) model think pair share adalah pembelajaran yang memberi siswa kesempatan untuk bekerja sendiri dan bekerjasama dengan orang lain.

$\begin{array}{cr}\text { Berdasarkan } & \text { beberapa } \\ \text { pendapat tersebut peneliti }\end{array}$ menyimpulkan model think pair share adalah model pembelajaran yang member kesempatan untuk bekerjasama mengembangkan kemampuan mengungkapkan ide atau gagasan dengan kata-kata secara verbal dan membandingkannya dengan ideide orang lain.

Menurut Arends (dalam Trianto, 2009: 81), ciri-ciri dari model think pair share adalah think (berpikir secara individual), pair (berpasangan dengan teman sebangku), dan share (berbagi jawaban dengan pasangan lain atau seluruh kelas). Ketiga tahapan ciri model cooperative learning tipe think pair share ini harus dilaksanakan secara berurutan dalam pembelajaran. 
Keunggulan dari model cooperative learning tipe think pair share menurut Lie (2005:46) adalah memungkinkan siswa untuk merumuskan dan mengajukan pertanyaan-pertanyaan mengenai materi yang diajarkan, siswa akan terlatih menerapkan konsep, siswa lebih aktif dalam pembelajaran, siswa memperoleh kesempatan untuk mempresentasikan hasil diskusinya,

dan memungkinkan guru untuk lebih banyak memantau siswa dalam proses pembelajaran. Sedangkan kelemahannya menurut Lie (2005:46) adalah banyak kelompok yang akan melapor dan perlu dimonitor, lebih sedikit ide yang muncul, dan tidak ada penengah jika terjadi perselisihan dalam kelompok. Langkahlangkah model cooperative learning tipe think pair share menurut Huda (20011: 136) adalah (1) siswa ditempatkan dalam kelompok-kelompok. Setiap kelompok terdiri dari empat anggota/siswa, (2) guru memberikan tugas pada setiap kelompok, (3) masing-masing anggota memikirkan dan mengerjakan tugas tersebut sendiri-sendiri terlebih dahulu, (4) kelompok membentuk anggotaanggotanya secara berpasangan,(5) setaip pasangan mendiskusikan hasil pengerjaan individunya, dan (6) kedua pasangan lalu bertemu kembali dalam kelompoknya masing-masing untuk menshare hasil diskusinya.
Aktivitas adalah kegiatan yang dilakukan seseorang dalam melakukan sesuatu. Menurut pendapat Sardiman (2010: 100) mengungkapkan bahwa aktivitas belajar adalah aktivitas yang bersifat fisik dan mental.

Sedangkan menurut Kunandar (2011: 277) aktivitas belajar adalah keterlibatan siswa dalam bentuk sikap, pikiran, perbuatan dan aktivitas dalam kegiatan pembelajaran guna menunjang keberhasilan proses belajar mengajar dan memperoleh manfaat dari kegiatan tersebut.

Berdasarkan pendapat para ahli di atas, dapat peneliti simpulkan bahawa aktivitas belajar merupakan aktivitas siswa yang bersifat fisik dan mental dalam proses pembelajaran guna mencapai belajar dalam bentuk sikap, pikiran, dan perhatian.

Menurut Hamalik (2009:

33) hasil belajar adalah bila seseorang telah belajar akan terjadi perubahan tingkah laku pada orang tersebut, misalnya dari tidak tahu menjadi tahu, dan dari tidak mengerti menjadi mengerti. Sedangkan menurut Gagne (dalam Yulmaiyer, 2007: 5) hasil belajar diperoleh setelah belajar berupa keterampilan, pengetahuan, sikap, dan nilai. Dalam lembaga pendidikan khususnya sekolah, hasil belajar yang dimaksud adalah hasil belajar dari proses pembelajaran yang mencakup ranah kognitif, afektif, dan psikomotor yang diperoleh 
siswa melalui interaksi dengan lingkuangan dan kondisi pembelajaran tertentu.

Berdasarkan

beberapa

pendapat para ahli di atas, dapat peneliti simpulkan hasil belajar adalah hasil yang diperoleh siswa melalui kegiatan interaksi dengan lingkungan dan kondisi pembelajaran tertentu berupa pengetahuan, keterampilan, dan nilai yang dapat dilihat dari hasil nilai ulangan harian (formatif), nilai ulangan tengah semester (subsumatif), dan nilai ulangan semester (sumatif).

Matematika sebagai suatu disiplin ilmu yang memiliki objek dasar yang berupa fakta, konsep, operasi, dan prinsip. Menurut Adji (2006: 34) mengemukakan bahwa matematika adalah bahasa, sebab matematika merupakan symbol yang berlaku secara universal dan sangat padat makna dan pengertian. Kemudian Wale (2006: 3) mengemukakan matematika sebagai ilmu yang memiliki pola keteraturan dan urutan yang logis.

Pembelajaran matematika di SD tidak terlepas dari hakikat peserta didik dan hakikat matematika. Matematika yang dipelajari di SD dapat digunakan pada kepentingan hidupnya seharihari dalam lingkungannya untuk membentuk pola pikir yang logis, sistematis, kritis, cermat, dan akhirnya dapat digunakan untuk mempelajari ilmu-ilmu yang lain.
Permendiknas no 22 berisi tentang standar isi tujuan matematika menyebutkan bahwa pembelajaran matematika pada satuan pendidikan SD/MI memiliki ruang lingkup yang meliputi aspek-aspek yaitu bilangan, geometri, pengukuran, dan pengolahan kata.

\section{METODE PENELITIAN}

Penelitian ini menggunakan jenis Penelitian Tindakan Kelas (PTK) yang dalam bahasa asing dikenal sebagai Classroom Action Research. Arikunto (2006: 2-3) mengemukakan bahwa penelitian tindakan kelas yaitu sebuah kegiatan penelitian yang dilakukan di kelas. Penelitian dilaksanakan yang terdiri dari perencanaan, pelaksanaan, pengamatan, dan refleksi.

Penelitian tindakan kelas dilaksanakan di SDN 1 Purwosari . Penelitian ini dilaksanakan pada semester genap, dengan lama penelitian 4 bulan. Subjek penelitian tindakan kelas adalah siswa dan guru kelas IV SDN 1 Purwosari dengan jumlah 24 orang siswa yang terdiri dari 9 orang siswa laki-laki dan 14 orang siswa perempuan.

Teknik pengumpulan data menggunakan teknik tes dan non tes. Teknik tes digunakan untuk mengumpulkan data yang bersifat kuantitatif berupa nilai-nilai siswa, untuk mengetahui hasil belajar 
siswa pada pembelajaran matematika melalui model cooperative learning tipe think pair share. Teknik non tes berupa observasi, digunakan untuk mengetahui apakah dengan penerapan model cooperative learning tipe think pair share dapat meningkatkan aktivitas siswa pada proses pembelajaran matematika. Alat pengumpulan data berupa lembar observasi, lembar tes formatif, dan dokumentasi.

\section{HASIL PENELITIAN DAN PEMBAHASAN}

Kegiatan pembelajaran siklus I pertemuan 1 dilaksanakan pada hari Kamis, 7 Februari 2013, pertemuan 2 dilakasanakan pada hari Senin, 11 Februari 2013, dan pertemuan 3 berupa pemberian tes formatif dilaksanakan pada hari Selasa, 12 Februari 2013. Materi yang diajarkan secara garis besar mengenai "Pecahan". Secara garis besar, kegiatan pembelajaran pada siklus I, yaitu (1) membagi siswa menjadi 8 kelompok secara hetergogen yang terdiri dari 5-6 siswa, (2) memberikan tugas pada setiap kelompok, (3) masingmasing anggota kelompok memikirkan (think) dan mengerjakan soal-soal tersebut secara individu, (4) kelompok memberntuk anggotanya secara berpasangan (pair), (5) setiap pasangan mendiskusikan soal-soal yang ada pada lembar soal yang sebelumnya telah dikerjakan secara individu dan menentukan jawaban yang dianggap paling tepat, (6) kedua pasangan kembali ke dalam kelompok besar untuk berbagi (share) hasil diskusi secara berpasangan sebelumnya, (7) setiap kelompok menuliskan hasil diskusi/berbagi (share) dari setiap pasangan pada lembar kerja siswa, dan (8) masing-masing kelompok mempresentasikan hasil diskusinya.

Hasil penelitian siklus I diperoleh rata-rata aktivitas siswa pada pertemuan 1 sebesar 51,44\%, sedangkan pada pertemuan 2 sebesar 54,38\%. Sehingga diperoleh rata-rata aktivitas siswa siklus I sebesar $52,91 \%$ dan termasuk dalam kualifikasi cukup aktif. Hal tersebut dipengaruhi oleh hasil kinerja guru dalam pelaksanaan pembelajaran dengan perolehan rata-rata kinerja guru siklus I pertemuan 1 sebesar $35,62 \%$ dan pada pertemuan 2 sebesar $45 \%$. Dengan demikian diperoleh rata-rata kinerja guru siklus I sebesar $40,31 \%$ dan termasuk dalam kualifikasi cukup. Persentase siswa tuntas mencapai $57,44 \%$, sedangkan persentase siswa belum tuntas mencapai $42,56 \%$ dengan perolehan nilai rata-rata kelas pada siklus I sebesar 60,53\%.

Kegiatan pembelajaran siklus II pertemuan 1 dilaksanakan pada hari Selasa, 19 Februari 2013, pertemuan 2 dilakasanakan pada hari Kamis, 21 Februari 
2013, dan pertemuan 3 berupa pemberian tes formatif dilaksanakan pada hari Selasa, 25 Februari 2013. Materi yang diajarkan secara garis besar mengenai "Pecahan". Secara garis besar, kegiatan pembelajaran pada siklus I, yaitu (1) membagi siswa menjadi 8 kelompok secara hetergogen yang terdiri dari 5-6 siswa, (2) memberikan tugas pada setiap kelompok, (3) masingmasing anggota kelompok memikirkan (think) dan mengerjakan soal-soal tersebut secara individu, (4) kelompok memberntuk anggotanya secara berpasangan (pair), (5) setiap pasangan mendiskusikan soal-soal yang ada pada lembar soal yang sebelumnya telah dikerjakan secara individu dan menentukan jawaban yang dianggap paling tepat, (6) kedua pasangan kembali ke dalam kelompok besar untuk berbagi (share) hasil diskusi secara berpasangan sebelumnya, (7) setiap kelompok menuliskan hasil diskusi/berbagi (share) dari setiap pasangan pada lembar kerja siswa, dan (8) masing-masing kelompok mempresentasikan hasil diskusinya.

Hasil penelitian siklus II diperoleh rata-rata aktivitas siswa pada pertemuan 1 sebesar $60,88 \%$, sedangkan pada pertemuan 2 sebesar 65,61\%. Sehingga diperoleh rata-rata aktivitas siswa siklus II sebesar $63,24 \%$ dan termasuk dalam kualifikasi aktif. Hal tersebut dipengaruhi oleh hasil kinerja guru dalam pelaksanaan pembelajaran dengan perolehan rata-rata kinerja guru siklus II pertemuan 1 sebesar $53,75 \%$ dan pada pertemuan 2 sebesar $60,62 \%$. Sehingga diperoleh rata-rata kinerja guru siklus II sebesar $57,18 \%$ dan termasuk dalam kualifikasi cukup. Secara keseluruhan persentase siswa tuntas pada siklus II mencapai $70,22 \%$, sedangkan persentase siswa belum tuntas pada siklus II mencapai 29,78\% dengan perolehan nilai rata-rata kelas siklus II sebesar 69,52.

Kegiatan pembelajaran siklus III pertemuan 1 dilaksanakan pada hari Selasa, 26 Februari 2013, pertemuan 2 dilakasanakan pada hari Kamis, 28 Februari 2013, dan pertemuan 3 berupa pemberian tes formatif dilaksanakan pada hari Senin, 4 Maret 2013. Materi yang diajarkan secara garis besar mengenai "Pecahan". Secara garis besar, kegiatan pembelajaran pada siklus I, yaitu (1) membagi siswa menjadi 8 kelompok secara heterogen yang terdiri dari 5-6 siswa, (2) memberikan tugas pada setiap kelompok, (3) masingmasing anggota kelompok memikirkan (think) dan mengerjakan soal-soal tersebut secara individu, (4) kelompok memberntuk anggotanya secara berpasangan (pair), (5) setiap pasangan mendiskusikan soal-soal yang ada pada lembar soal yang sebelumnya telah dikerjakan 
secara individu dan menentukan jawaban yang dianggap paling tepat, (6) kedua pasangan kembali ke dalam kelompok besar untuk berbagi (share) hasil diskusi secara berpasangan sebelumnya, (7) setiap kelompok menuliskan hasil diskusi/berbagi (share) dari setiap pasangan pada lembar kerja siswa, dan (8) masing-masing kelompok mempresentasikan hasil diskusinya.

Hasil penelitian siklus III diperoleh rata-rata aktivitas siswa pada pertemuan 1 sebesar 74,94\%, sedangkan pada pertemuan 2 sebesar $\quad 80,06 \%$. Sehingga diperoleh rata-rata aktivitas siswa siklus III sebesar 77,49\% dengan kualifikasi aktif. Hal tersebut dipengaruhi oleh hasil kinerja guru dalam pelaksanaan pembelajaran dengan perolehan rata-rata kinerja guru siklus III pertemuan 1 sebesar $69,37 \%$ dan pada pertemuan 2 sebesar $75,62 \%$. Sehingga diperoleh rata-rata kinerja guru siklus III sebesar $72,49 \%$ dengan kualifikasi baik. Secara keseluruhan persentase siswa tuntas pada siklus III mencapai $85,11 \%$, sedangkan persentase siswa belum tuntas pada siklus III mencapai $14,89 \%$ dengan perolehan nilai rata-rata kelas siklus III sebesar 79,25.

Rekapitulasi terhadap hasil penelitian pada siklus I, II, dan III yang dilakukan oleh peneliti adalah sebagai berikut:

Tabel 1. Rekapitulasi Persentase Aktivitas Siswa Per-Siklus

\begin{tabular}{|l|c|c|c|c|c|c|}
\hline \multirow{2}{*}{ No. } & \multicolumn{6}{|c|}{ SIKLUS } \\
\cline { 2 - 7 } & \multicolumn{2}{|c|}{ I } & \multicolumn{2}{c|}{ II } & \multicolumn{2}{c|}{ III } \\
\cline { 2 - 7 } & Pr. 1 & Pr. 2 & Pr. 1 & Pr. 2 & Pr. 1 & Pr. 1 \\
\hline Aspek & 51,44 & 54,38 & 60,88 & 65,61 & 74,94 & 80,06 \\
$(\%)$ & $(\%)$ & $(\%)$ & $(\%)$ \\
Aktivitas & $(\%)$ & $(\%)$ & $(\%)$ & \multicolumn{2}{c|}{$63,24(\%)$} & \multicolumn{2}{c|}{$77,49 \%$} \\
\hline Rata-rata & \multicolumn{2}{|c|}{$52,91(\%)$} & \multicolumn{2}{c|}{ Aktif } & \multicolumn{2}{c|}{ Aktif } \\
\hline Kriteria & \multicolumn{2}{|c|}{ Cukup Aktif } & \multicolumn{3}{c|}{$14,25(\%)$} \\
\hline Peningkatan & \multicolumn{3}{|c|}{$10,33(\%)$} & \multicolumn{3}{c}{} \\
\hline
\end{tabular}

Keterangan:

Pr: Pertemuan

Rekapitulasi persentase aktivitas siswa dalam siklus penelitian dapat juga ditunjukkan pada grafik berikut.

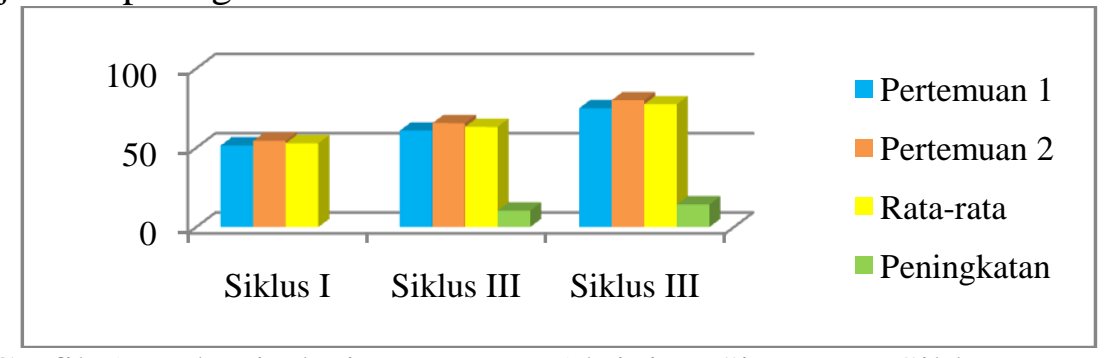

Grafik 1. Rekapitulasi Persentase Aktivitas Siswa Per-Siklus 
Rekapitulasi persentase kinerja guru dalam proses pembelajaran dapat diamati pada tabel berikut.

Tabel 2. Rekapitulasi Persentase Kinerja Guru Per-Siklus

\begin{tabular}{|l|c|c|c|c|c|c|}
\hline \multirow{3}{*}{ No. } & \multicolumn{6}{|c|}{ SIKLUS } \\
\cline { 2 - 7 } & \multicolumn{3}{|c|}{ I } & \multicolumn{2}{|c|}{ II } & \multicolumn{2}{c|}{ III } \\
\cline { 2 - 7 } & Pr. 1 & Pr. 2 & Pr. 1 & Pr. 2 & Pr. 1 & Pr. 1 \\
\hline $\begin{array}{l}\text { Aspek } \\
\text { Kinerja } \\
\text { Guru }\end{array}$ & $\begin{array}{c}35,62 \\
(\%)\end{array}$ & $\begin{array}{c}45 \\
(\%)\end{array}$ & $\begin{array}{c}53,75 \\
(\%)\end{array}$ & $\begin{array}{c}60,62 \\
(\%)\end{array}$ & $\begin{array}{c}69,73 \\
(\%)\end{array}$ & $\begin{array}{c}75,62 \\
(\%)\end{array}$ \\
\hline Rata-rata & \multicolumn{2}{|c|}{$40,31(\%)$} & \multicolumn{2}{|c|}{$57,18(\%)$} & \multicolumn{2}{c|}{$72,49 \%$} \\
\hline Kriteria & \multicolumn{2}{|c|}{ Cukup } & \multicolumn{3}{c|}{ Cukup } & \multicolumn{2}{c|}{ Baik } \\
\hline Peningkatan & \multicolumn{2}{|c|}{$16,87(\%)$} & \multicolumn{3}{c|}{$15,31(\%)$} \\
\hline
\end{tabular}

Rekapitulasi persentase kinerja guru pada Tabel 2 dapat juga ditunjukan dalam grafik di bawah ini.

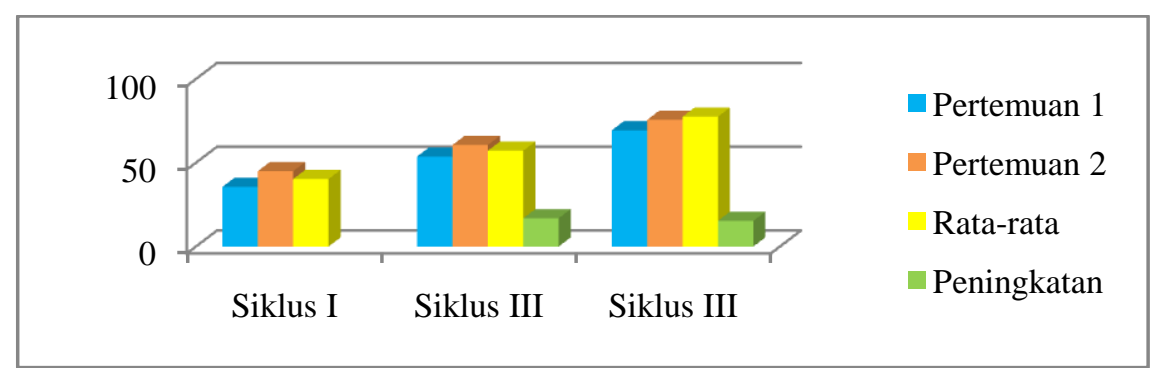

Grafik 2. Rekapitulasi Persentase Kinerja Guru Per-Siklus

Rekapitulasi persentase ketuntasan belajar siswa dalam proses pembelajaran dapat diamati pada tabel berikut.

Tabel 3. Rekapitulasi Persentase Ketuntasan Belajar Siswa Per-Siklus

\begin{tabular}{|c|c|c|c|c|c|c|}
\hline \multirow{2}{*}{ Nilai } & \multicolumn{6}{|c|}{ SIKLUS } \\
\cline { 2 - 7 } & \multicolumn{2}{|c|}{ I } & \multicolumn{2}{|c|}{ II } & \multicolumn{2}{c|}{ III } \\
\cline { 2 - 7 } & siswa & $\%$ & siswa & $\%$ & siswa & $\%$ \\
\hline$<60$ & 10 & 42,56 & 7 & 29,78 & 3 & 14,89 \\
\hline$\geq 60$ & 14 & 57,44 & 17 & 70,22 & 21 & 85,11 \\
\hline Peningkatan & \multicolumn{3}{|c|}{12,78} & \multicolumn{3}{c|}{14,89} \\
\hline
\end{tabular}

Rekapitulasi persentase ketuntasan belajar siswa pada Tabel 3 dapat juga ditunjukan dalam grafik di bawah ini. 


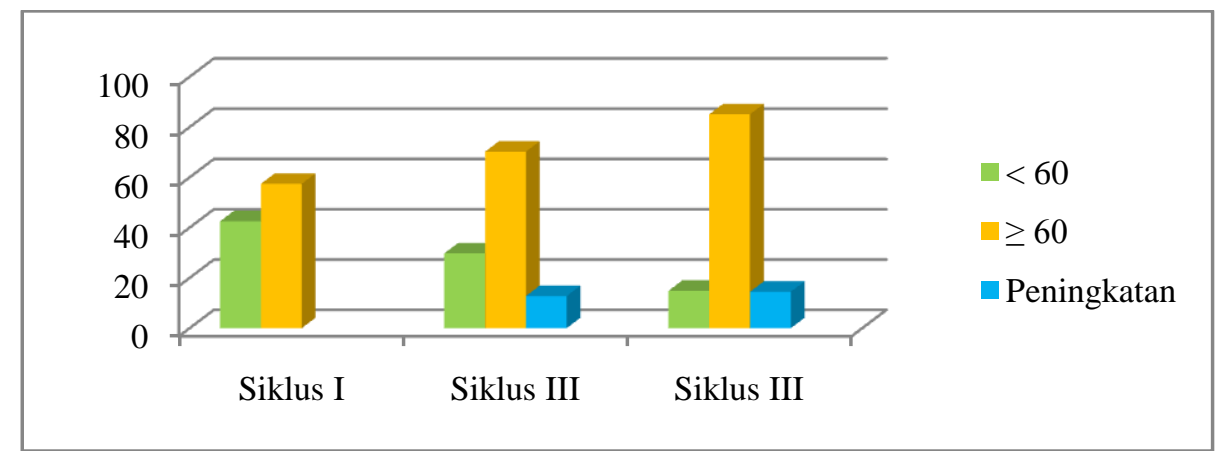

Grafik 3. Rekapitulasi Persentase Ketuntasan Belajar Siswa Per-Siklus

Hasil yang diperoleh siswa setelah pelaksanaan siklus adalah terjadinya peningkatan baik pada aktivitas maupun hasil belajar siswa. Salah satu faktor yang mempengaruhi aktivitas dan hasil belajar siswa di kelas adalah kinerja guru dalam melaksankan langkah-langkah perbaikan yang menerapkan model cooperative learning tipe think pair share.

Berdasarkan analisis data pada siklus I persentase aktivitas siswa masih dalam kualifikasi "cukup aktif". Sebagaimana aspek dalam aktivitas siswa yang diamati adalah memperhatikan penjelasan guru, bertanya pada guru, aktif menjawab pertanyaan guru, mengerjakan tugas secara individual (think), kerja sama mengerjakan tugas dengan teman sebangku/berpasangan (pair), kerja sama mengerjakan tugas dalam diskusi kelompok besar (share), ketepatan waktu dalam menyelesaikan tugas, dan mempresentasikan hasil diskusi kelompok. Beberapa aspek aktivitas siswa yang berhubungan dengan kegiatan kerja sama masih cenderung rendah, hal tersebut dapat diamati dari masih adanya siswa yang kurang antusias bekerja sama dengan pasangannya maupun kelompoknya. Selain itu, siswa masih kebingungan dalam menpresentasikan hasil kerja kelompoknya. Hanya beberapa siswa yang antusias dalam kegiatan bekerja sama.

Pada siklus II persentase aktivitas siswa memperoleh ratarata sebesar $63,24 \%$, meningkat pada siklus III menjadi $747,49 \%$. Persentase aktivitas mengalami peningkatan pada setiap siklusnya. Mayoritas siswa sudah mampu bekerja sama dengan baik dalam menyelesaikan tugas baik secara berpasangan maupun kelompok diskusi. Interaksi dalam bekerja sama menunjukkan setiap anggota dalam kelompok ambil bagian dalam menyelesaikan tugas maupun saat mepresentasikan hasil diskusi. Hal tersebut sejalan dengan pendapat Kunandar (2011: 
277) aktivitas belajar adalah keterlibatan siswa dalam bentuk sikap, pikiran, perbuatan dan aktivitas dalam kegiatan pembelajaran guna menunjang keberhasilan proses belajar mengajar dan memperoleh manfaat dari kegiatan tersebut. Indikator aktivitas siswa dapat dilihat dari mayoritas siswa beraktivitas, aktivitas pembelajaran didominasi oleh kegiatan siswa, mayoritas siswa mampu mengerjakan tugas yang diberikan guru dalam LKS.

Berdasarkan persentase ketuntasan belajar siswa, hasil belajar siswa dalam pembelajaran matematika dengan menggunakan model cooperative learning tipe think pair share menunjukkan adanya peningkatan pada setiap siklusnya. Pada siklus I sebesar $57,44 \%$. Selanjutnya pada siklus II persentase ketuntasan meningkat sebesar $12,78 \%$ menjadi $70,22 \%$. Dan pada siklus III persentase ketuntasan meningkat sebesar 14,89\% menjadi $85,11 \%$.

Berdasarkan hasil temuan yang telah peneliti paparkan di atas, diperoleh keterangan bahwa indikator keberhasilan tindakan yang ditetapkan telah tercapai, yaitu persentase siswa aktif dan ketuntasan belajar siswa secara klasikal $\geq 75 \%$. Dengan demikian, penelitian pada siswa kelas IV SDN 1 Purwosari Tahun Pelajaran 2013/2014 ini selesai.

\section{KESIMPULAN DAN SARAN}

Berdasarkan analisis hasil penelitian, dapat disimpulkan bahwa penerapan model cooperative learning tipe think pair share pada pembelajaran matematika dapat meningkatkan aktivitas dan hasil belajar siswa kelas IV SDN 1 Purwosari Tahun Pelajaran 2013/2014. Hal tersebut ditunjukkan melalui hasil analisis data aktivitas dan hasil belajar siswa. Persentase aktivitas siswa pada siklus I sebesar 52,91\% (cukup aktif), pada siklus II sebesar 63,24\% (aktif), dan pada siklus III sebesar 77,49\% (aktif). Dan persentase ketuntasan belajar siswa siklus I sebesar $57,44 \%$ menjadi $70,22 \%$ di siklus II dan kembali meningkat menjadi $85,11 \%$ pada siklus III.

\section{DAFTAR PUSTAKA}

Adji, Nahrowi \& Maulana. 2006. Pemecahan Masalah Matematika. Bandung: UPI PRESS.

Arikunto, Suharsimi. 2006. Penelitian Tindakan Kelas. Jakarta: Bumi Aksara.

Hamalik, Oemar. 2009. Proses Belajar Mengajar. Jakarta: Bumi Aksara. 
Heruman. 2008. Model

Pembelajaran Matematika

di Sekolah Dasar.

Bandung: PT Remaja

Rosdakarya.

Huda, Miftahul. 2011. Cooperative Learning Metode, Teknik, Struktur dan Model Penerapan. Yogyakarta: Pustaka Pelajar.

Komalasari, Kokom. 2011. Pembelajaran Kontekstual Konsep dan Aplikasi. Bandung: Refika Aditama.

Kunandar. 2011. Langkah Mudah Penelitian Tindakan Kelas Sebagai Pengembangan Profesi. Jakarta : PT Raja Grafindo Persada.

Lie, Anita. 2005. Cooperative Learning, Mempraktekkan Cooperative Learning Di Ruang-ruang Kelas. Jakarta: Grassindo.

Sardiman. 2010. Interaksi \& Motivasi Belajar Mengajar. Jakarta: Alfabeta.

Trianto. 2009. Mendesain Model Pembelajaran Inovatif Progresif. Jakarta: Kencana Prenada Media Group.
Wale, Jhon A. 2006. Elementary and Middle School Mathematics (Matematika Sekolah Dasar dan Menengah). Jakarta: Erlangga.

Yulmaiyer. 2007. Penggunaan Kamus Bahasa Indonesia untuk Memperkaya Perbendaharaan Kata dalam Mata Pelajaran Bahasa Indonesia. Lampung: Proposal PTK. 